\title{
FRIENDSHIP AS SHARED JOY IN NIETZSCHE
}

\author{
Daniel I. Harris (Hunter College)
}

Nietzsche criticizes the shared suffering of compassion as a basis for ethics, yet his challenge to overcome compassion seeks not to extinguish all fellow feeling but instead urges us to transform the way we relate to others, to learn to share not suffering but joy. For Schopenhauer, we act morally when we respond to another's suffering, while we are mistrustful of the joys of others. Nietzsche turns to the type of relationality exemplified by friendship, understood as shared joy, in order to help him to articulate his ethical ideal for human beings.

Writing of Friedrich Nietzsche, her friend, Ida Overbeck relates that while working on Human, All too Human:

A bad chapter of Schopenhauer affected Nietzsche especially strongly, the idea that man is not constituted to share joy, and can be interested in another person's misfortune or well-being only temporarily by the detour of former participation in misfortune; that well-being on the contrary, is suited to arouse envy; wherefore he concluded also from other premises, that hardship is the real positive condition of the human race, and that only pity can be the real well-spring of morality. ${ }^{1}$

Nietzsche would write of Human, All too Human in his autobiography, "I used it to liberate myself from things that did not belong to my nature." 2 After a decade of admiration for Schopenhauer, Nietzsche began to reject the focus on suffering and compassion as a basis for ethics he found there. Instead, in his middle period, Nietzsche begins to seek some route to sharing life with others that does not travel through suffering. Rather than the suffering-with [Mitleid] of compassion, Nietzsche begins to write of Mitfreude, joying-with:

\footnotetext{
${ }^{1}$ Ida Overbeck, "Errinerungen," in Conversations with Nietzsche: A Life in the Words of His Contemporaries, (ed.) S. Gilman, (tr.) D. Parent (New York: Oxford University Press, 1987), 110.

2 Friedrich Nietzsche, Ecce Homo, (tr.) J. Norman, (ed.) A. Ridley and J. Norman (New York: Cambridge University Press, 2005), 115.
} 
Joying with. - The serpent that stings us means to hurt us and rejoices as it does so; the lowest animal can imagine the pain of others. But to imagine the joy of others and to rejoice at it is the highest privilege of the highest animals, and among them it is accessible only to the choicest exemplars - thus a rare humanum: so that there have been philosophers who have denied the existence of joying with. ${ }^{3}$

Alluding to Schopenhauer in the final line, Nietzsche marks as high, exemplary and rare the capacity to share in joy rather than suffering. Nietzsche will link shared joy to friendship, where the other's joy paradigmatically invites not envy but celebration, and so now gives more consistent and systematic attention to friendship than at any other place in his body of work. He writes now in a notebook that, pointing first to Schopenhauer's formulation, "an ethics of compassion must be complemented by an even higher ethics of friendship." 4 Nietzsche entrusts his turn from suffering towards joy not to a sovereign individual, not to a hermit or a nomad, but to a friend: "Friend. - Fellow rejoicing [Mitfreude], not fellow suffering [Mitleiden], makes the friend." (HH, 180)

In this paper, I argue that the centrality of Mitfreude in Nietzsche's conception of friendship helps us to understand Nietzsche's ethics more generally. Nietzsche seeks to articulate and defend a stance towards our existence, and he discusses this stance in terms of affirmation. I am to establish that Nietzsche uses the type of relationality fostered by friendship as a model for the type of affirmation he would have us cultivate with our world, so that to cultivate healthy friendships is to cultivate a healthy, affirmative stance towards our existence. Nietzsche links joy with desire, temptation, and experimentation and weaves each of these through his unique picture of a new type of affirming, yes-saying spirit. Joy figures in each of the concepts Nietzsche develops to help him to articulate how human beings can best affirm their existence, in eternal recurrence, self-overcoming, and in amor fati, and so joy's central place in friendship gives us reason to investigate friendship's role in the processes through which we become the beings that we are. I suggest that the type of strength Nietzsche applauds in individuals is one that makes

\footnotetext{
${ }^{3}$ Friedrich Nietzsche, Human, All too Human, (tr.) R. Hollingdale (New York: Cambridge University Press, 1986), 228. Hereafter referred to parenthetically in the text as $\mathrm{HH}$.

${ }^{4}$ Friedrich Nietzsche, Kritische Studienausgabe, vol. 8, (ed.) G. Colli, M. Montinari (Berlin: Walter de Gruyter, 1980), 333.
} 
a virtue of giving, what I call a "strong surrendering," and I show that the features of friendship that animate Nietzsche's account enable just such a stance. We are, Nietzsche suggests, beings who become through surrender to cultural and intersubjective forces of meaningproduction, and one of the central ways we are given to so surrender ourselves is through friendship.

\section{Schopenhauer, Suffering, and the Value of Existence}

Nietzsche first read Schopenhauer's The World as Will and Representation in 1865 , at 21 , and quickly became enamored, feeling a special affinity for the man and his work. Yet at least by the end of 1876 , Nietzsche's letters reveal a break with Schopenhauer's thought, clear in $H H$ published in 1878, and perhaps already in Schopenhauer as Educator, published in $1874 . .^{5}$ This break cannot be understood apart from Nietzsche's upward revaluation of suffering that casts as unhealthy Schopenhauer's ethics of compassion, coupled with an insistence that whatever the value of suffering, joy, and the sharing of it, remain possible, that we can relate to each other otherwise than through suffering.

For Schopenhauer, the ubiquity of suffering and our ethical response to it in compassion follow from the metaphysical nature of existence. The world in itself is will, and what will wills is the empirical world of appearance or representation. Human beings, rocks, gravity, are all manifestations of a single will, their differences belonging to the world of appearance and so papering over the fundamental oneness of a world of will. The will is like a god insofar it is a single principle that explains the varied features of our world, but is otherwise ungodly. Will is a blind, aimless striving without the possibility for satiety, the driving beat of existence. David Berman encourages us to imagine an "omnipotent animal of insatiable hun-

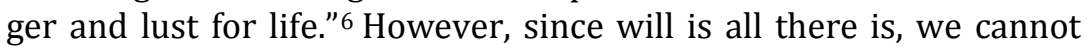
contrast this animal with a separate world for which it hungers: the world as will consumes itself like a many-headed animal devouring its many parts.

\footnotetext{
${ }^{5}$ See Thomas Brobjer, "Nietzsche as German Philosopher: His Reading of the Classical German Philosophers," in Nietzsche and the German Tradition, (ed.) N. Martin (Berlin: Peter Lang, 2003), 45-60.

${ }^{6}$ David Berman, "Schopenhauer and Nietzsche: Honest Atheism, Dishonest Pessimism," in Willing and Nothingness: Schopenhauer as Nietzsche's Educator, (ed.) C. Janaway (Oxford: Clarendon Press, 1998), 183.
} 
If will exhausts existence, and if will is essentially striving, then there could exist nothing to satisfy that striving-there is simply nothing besides the everything of the will. This unsatisfied striving, then, is the basic condition of existence. Schopenhauer writes, "at all grades of its phenomenon from the lowest to the highest, the will dispenses entirely with an ultimate aim and object. It always strives, because striving is its sole nature, to which no attained goal can put an end. Such striving is therefore incapable of final satisfaction; it can be checked only by hindrance, but itself it goes for ever." ${ }^{7}$ Schopenhauer will call the state of unsatisfied striving suffering. Since existence is unsatisfied striving, existence is suffering. "Essentially," he writes, "all life is suffering." (WW1, 310) And here is the heart of Schopenhauer's pessimism: life is suffering, so whatever is the value of suffering is ipso facto the value of life itself. Schopenhauer will argue that suffering should be abolished, and so life itself should be abolished. "Nothing else can be stated as the aim of our existence," he writes, "except the knowledge that it would be better for us not to exist." (WW2, 605)

Schopenhauer's metaphysics complements and provides moral justification for his account of the ethical situation of human beings. Ethics is the ground of metaphysics because it is only insofar as human beings encounter a world of suffering and seek to understand their place in it that they begin to ask the questions of metaphysics, which is to say they begin to ask how such a world of suffering could be justified. A metaphysical system succeeds insofar as it explains and so provides moral justification for the world. Schopenhauer follows Kant in insisting that actions done from self-interest can have no moral worth, that moral worth follows instead from benevolent motives that take the interests of others as our own, and argues that taking the interests of others as our own is accomplished only in acts of compassion. "Only insofar as an action has sprung from compassion does it have moral value; and every action resulting from other motives has none." ${ }^{8}$ If individuation is phenomenal, and at a more fundamental level the world of appearance is the expression of one will, then the ontic differences between human beings lose their moral importance. Compassion is the basis of morality for Schopen-

\footnotetext{
${ }^{7}$ Arthur Schopenhauer, The World as Will and Representation, (tr.) E. Payne (New York: Dover, 1958), 308. Hereafter referred to parenthetically in the text as WW1 and WW2.

${ }^{8}$ Arthur Schopenhauer, On the Basis of Morality, (tr.) E. Payne (Indianapolis: Hackett Publishing, 1995), 144. Hereafter referred to parenthetically in the text as BM.
} 
hauer because through it we succeed in pushing past the ontic differences between individuals; the good person's identification of her interests with suffering of others, "is a reminder of that respect in which we are all one and the same entity." (BM, 210-11)

Compassion for Schopenhauer is the practical expression of the proper theoretical view of the world, so long as we understand the "co" of compassion and the "mit" of Mitleid carefully. Good characters experience the pain of others as their own insofar as they understand the phenomenal differences that separate egos as following from a more primal oneness. The pain is felt as belonging to the other even as we accord it the same prominence of place in our deliberations we do our own, and so the gulf that separates us is bridged. Schopenhauer writes, "as soon as compassion is aroused, the weal and woe of another are nearest to my heart in exactly the same way, although not always in the same degree, as otherwise only my own are. Hence the difference between him and me is no longer absolute...the non-ego has to a certain extent become the ego." (BM, 144) Taking the other's suffering on as one's own is possible only because we are in fact not separate beings, and so the experience of compassion is, for Schopenhauer, a kind of moral mystery, the truth of the unity of will breaking through phenomenal individuation like the sun breaking through clouds.

The compassionate are able to see through the individuation of the phenomenal, to see suffering not as deserved by agents in isolation, but as the nature of existence itself. Not agents who do particular wrongs, but a world that is itself carved from suffering, is responsible for the wretchedness of the world. Although the world suffers, it is also the tormentor, and so suffering exists in exact proportion to existence's guilt, the animal eats only itself: "In this sense we can say that the world itself is the tribunal of the world. If we could lay all the misery of the world in one pan of the scales, and all the guilt in the other, the pointer would certainly show them to be in equilibrium." (WW1, 352) The world can be judged as a whole, and found guilty as a whole, and so has a meaning, as a whole. "This very real world of ours with all its suns and galaxies, is-nothing." (WW1, 412)

\section{Nietzsche and the Affirmation of Suffering}

Nietzsche too will call the world a whole, but will rail against Schopenhauer's insistence that the world could be judged, writing, "...there is nothing that can judge, measure, compare, or condemn 
our being, because that would mean judging, measuring, comparing, and condemning the whole.... But there is nothing outside the whole!" 9 Nietzsche will grow into himself in part through distancing himself from Schopenhauer's attempt to behold the world from outside of it. Crucial to this is a revaluation of suffering and our response to it in compassion.

Nietzsche discusses compassion in every one of his published works. ${ }^{10}$ His criticisms of compassion as a moral emotion can be divided into two types that distinguish his concerns both chronologically and thematically. First, Nietzsche charges that Schopenhauer misunderstands the psychological basis of compassion. In HH, Daybreak $^{11}$, and The Gay Science ${ }^{12}$, Nietzsche complicates the story that Schopenhauer tells about the exercise of compassion by suggesting a rival account of what motivates the compassionate. Second, and subsequently, Nietzsche comes to question compassion as a symptom of cultural decline. Beginning in $D$ and $G S$, then especially in Thus Spoke Zarathustra ${ }^{13}$ and beyond, Nietzsche suggests that compassion shows up as desirable only within the horizon of the lamentable movement of slave morality. He attacks the background commitments of slave morality that cast compassion as a valuable moral emotion, urging his readers to overcome compassion as a way of overcoming themselves.

\footnotetext{
${ }^{9}$ Friedrich Nietzsche, Twilight of the Idols, (tr.) J. Norman, (ed.) A. Ridley and J. Norman (New York: Cambridge University Press, 2005), 182.

${ }_{10}$ Mitleid is importantly difficult to translate. The German is ambiguous among pity, compassion and sympathy; the latter two have the etymological benefit of showing that we are speaking of a shared feeling, while the former does a better job of capturing the suffering that figures in the phenomenon. Kaufmann and Hollingdale have generally preferred "pity" when translating Nietzsche. Clark and Swenson in their translation of Nietzsche's Genealogy render Mitleid as "compassion." Pity carries pejorative overtones that compassion does not, and so it is no surprise that translators of a Nietzsche almost universally critical of the emotion have preferred to render Mitleid as pity. Nietzsche's criticism of Mitleid, however, is that it paradigmatically contains the pejorative aspects associated with pity but ostensibly absent in compassion. Rendering Mitleid as pity blunts the edge of Nietzsche's criticism here: Nietzsche's target is the ideal of a shared suffering that does not diminish the other, compassion rather than pity.

${ }^{11}$ Friedrich Nietzsche, Daybreak, (tr.) R. Hollingdale (New York: Cambridge University Press, 1982). Hereafter referred to parenthetically in the text as D.

12 Friedrich Nietzsche, The Gay Science, (tr.) W. Kaufmann (New York: Vintage Books, 1974). Hereafter referred to parenthetically in the text as GS.

13 Friedrich Nietzsche, Thus Spoke Zarathustra, (tr.) R. Hollingdale (Middlesex: Penguin Books, 1969). Hereafter referred to parenthetically in the text as Z.
} 
The first plane of Nietzsche's criticism of compassion is psychological. For Schopenhauer, only benevolent unegoistic actions have moral worth, only acts done out of compassion are so unegoistic, and thus only acts done out of compassion have moral worth. Nietzsche dismisses the distinction between egoism and non-egoism: "under strict examination the whole concept 'unegoistic action' vanishes into thin air." $(\mathrm{HH}, 71)$ Nietzsche suggests that we look more closely at compassion to see its many tangled motivating roots. He writes:

Pity has the pleasure of the other as its objective just as little as
wickedness has the pain of the other as such. For it conceals with-
in itself at least two (perhaps many more) elements of a personal
pleasure and is to that extent self-enjoyment: first as the pleasure
of the emotion...and then, when it eventuates in action, as the
pleasure of gratification in the exercise of power. If, in addition to
this, a suffering person is very close to us, we remove from our-
selves the suffering we ourselves feel by performing an act of
pity. (HH, 55-56)

The comparison with wickedness or malice is apt. The malicious seek to cause another's pain, the compassionate to alleviate it. In the case of malice, we are prepared to accept that the malicious want the other's pain not in itself but as an expression of their power over him. Acts of malice are pathological; they are the resultants of certain needs of the agents and, whatever their immediate aims, they exist because of their pathological function. Nietzsche's suggestion is that compassion follows the same path: the compassionate seek the alleviation of suffering not in itself but as an expression of power. Compassionate acts may involve conscious intentions to reduce suffering, but they exist because of their pathological function, because of what they accomplish for an agent.

It is important to stress, therefore, that when Nietzsche speaks of the egoism in compassion, the conception of egoism that renders his view most plausible requires that the egoistic element of an action may and does remain unconscious for the agent herself. Agents can be self-deceived about their motives; acts of compassion can be consciously well-intentioned and nevertheless egoistic; and Mitleid could owe its presence in a moral landscape to its egoistic effects without compassionate individuals consciously aiming at those effects. Nietzsche writes, for instance, that "the truth is: in the feeling of pity - I mean in that which is usually and misleadingly called pity - we are, to be sure, not consciously thinking of ourself but are doing so very strongly unconsciously..." (D, 83-84) And elsewhere in $D$, Nietzsche insists, "I deny morality as I deny alchemy, that is, I deny 
their premises: but I do not deny that there have been alchemists who believe in these premises and acted in accordance with them." (D, 60) That an act of compassion "conceals within itself" moments of egoism should be read as suggesting that those moments are concealed even from the agent herself. This is the sort of account we are prepared to accept in the case of malicious actions, and Nietzsche means to show that compassion mirrors malice in these crucial respects.

In $D$, Nietzsche explores the various ways that we come to the aid of those for whom we care, expressions of compassion through which, in very Schopenhaurian language, "the gulf between us and him seems to be bridged, an approximation to identity seems to occur." (D, 87) But, Nietzsche suggests, expressing compassion ultimately "produces in us great joy and exultation." He continues, "in all this, however, we have the enjoyment of active gratitude which, in short, is benevolent revenge." (D, 87-88) If compassion is refused, we grow hurt and disgruntled, robbed of the opportunity to enjoy ourselves at the other's expense. "Even in the most favourable case, there is something degrading in suffering and something elevating and productive of superiority in pitying - which separates these two sensations from one another to all eternity." (D, 88) There is, then, an irony endemic to compassion: just where one understanding sees the gulf between beings bridged as the suffering of one is taken on by the other, Nietzsche sees a fundamental distancing, an expression of power that robs the recipient of her dignity. "To offer pity is as good as to offer contempt." $(\mathrm{D}, 86)$

Nietzsche also suggests that in compassion we are only ever dealing with our own suffering, and help others only as a means to helping ourselves. That is, the mit of Mitleid and "co" of compassion are disingenuous. Nietzsche plays on words when as he suggests, "that pity [Mitleiden], on the other hand, is the same kind of thing as the suffering [mit dem Leiden] at the sight of which it arises, or that it possesses an especially subtle, penetrating understanding of suffering, are propositions contradicted by experience, and he who glorifies pity precisely on account of these two qualities lacks adequate experience in this very realm of the moral." (D, 84-85) The suffering of the other makes us uncomfortable; if we act towards the sufferer, "it is only this suffering of our own which we get rid of when we perform deeds of pity." (D, 84) Schopenhauer needs the compassionate to share the other's own suffering, and here Nietzsche disputes this as a possibility. He calls Schopenhauer's conception of compassion a "thoughtlessness" that fails to seek out the many drives that figure in actions called compassionate. "We never do anything of this kind out 
of one motive." (D, 84) Thus, Nietzsche comes to regard Schopenhauer as dealing with a compassion only "imperfectly" observed. (D, 85) When we look more closely at the place of compassion in the economy of our moral life, Nietzsche argues that we see a knot of egoistic motives that belie the place of prominence Schopenhauer would have compassion occupy.

Beginning in $D$ and $G S$, then predominantly in $Z$, Beyond Good and Evil ${ }^{14}$, On the Genealogy of Morality ${ }^{15}$, and The Antichrist ${ }^{16}$, Nietzsche situates his previously psychological criticisms of compassion in a broader cultural criticism of a form of life that would valourize it. Where Nietzsche first wants to cast the unegoistic as impossible, conceptually confused, his criticisms now begin to turn on the value of compassion. By attending to all suffering as an evil to be extinguished, Nietzsche suggests, we deny the ennobling aspects of suffering, and in doing that we grow forgetful of the ennoblement of humanity in general. A culture that flees suffering no longer desires to become anything new, to be other than it is, and reposes instead in an insipid, pale belief in itself. Nietzsche increasingly wants to point us beyond suffering, writing, "there are problems that are higher than any problems of pleasure, pain, or pity; and any philosophy that stops with these is a piece of naiveté."17

Nietzsche's preface to his $G M$ is important in understanding this eclipse of the psychological by the genealogical. Rather than focussing on the complex motivation of the compassionate, Nietzsche there wants to subsume such psychological points within a genealogical narrative that shows how compassion was able to assume a place of prominence in our moral thinking. Compassion becomes important for Nietzsche as symptom:

Precisely here I saw the great danger to humanity, its most sublime lure and temptation-and into what? Into nothingness?precisely here I saw the beginning of the end, the standstill, the backward-glancing tiredness, the will turning against life, the last sickness gently and melancholically announcing itself: I understood the ever more widely spreading morality of compassion-

\footnotetext{
${ }^{14}$ Friedrich Nietzsche, Beyond Good and Evil, (tr.) J. Norman, (ed.) R. Horstmann, J. Norman (New York: Cambridge University Press, 2002).

15 Friedrich Nietzsche, On the Genealogy of Morality, (tr.) M. Clark and A. Swenson (Indianapolis: Hackett Publishing, 1988).

16 Friedrich Nietzsche, The Anti-Christ, (tr.) J. Norman, (ed.) A. Ridley and J. Norman (New York: Cambridge University Press, 2005).

17 Nietzsche, Beyond Good and Evil, 117.
} 
which seized even the philosophers and made them sick-as the most uncanny symptom of our uncanny European culture... ${ }^{18}$

Not whether it is in fact possible to share in another's suffering, but what had to occur in a culture for it to seem possible and desirable now becomes Nietzsche's question. Nietzsche describes what can happen once one begins to pull on this kind of thread:

This problem of the value of compassion and of the morality of compassion...appears at first to be only an isolated matter, a lone question mark; whoever sticks here for once, however, and learns to ask questions here, will fare as I have fared: - an immense new vista opens up to him, a possibility takes hold of him like a dizziness, every sort of mistrust, suspicion, fear springs forth, the belief in morality, in all morality totters...for once the value of these values must itself be called into question. ${ }^{19}$

Nietzsche sees slave morality as urging the blanket condemnation of suffering, as claiming that suffering can have no value and is instead evidence of the meaninglessness of our human condition. Compassion is the response that says suffering can never have value, the slave is the type that refuses to see value in suffering, and so the morality of compassion or shared suffering is the morality of the slave. Nietzsche's question is, given that suffering is an ineradicable condition of human life, whether we ought to be the type of being that denigrates the very conditions of its existence.

Nietzsche suggests that a culture that seeks to obliterate pain, "desires, first and foremost, that all the dangers which life once held should be removed from it." He asks: "are we not, with this tremendous objective of obliterating all the sharp edges of life, well on the way to turning mankind into sand? Sand! Small, soft, round, unending sand!" (D, 105-106) If we understand suffering as an affront and overvalue the security of comfort, then for Nietzsche we make the world into something fallen, something at odds with our better nature. In $G S$, Nietzsche suggests that compassion leaves us deaf to the ways in which suffering can figure in human lives in beautiful ways. Nietzsche writes that those who would show him compassion know nothing of "the whole economy of my soul and the balance effected by 'distress,' the way new springs and needs break open, the way in which old wounds are healing, the way whole periods of the

\footnotetext{
18 Nietzsche, Genealogy, 4.

19 Ibid., 5 .
} 
past are shed..." (GS, 269) Those who want to get rid of suffering seek only, "the religion of comfortableness." (GS, 270) To see the point of this life as being comfortable is to see this life as unimportant, the way that being comfortable while travelling can mean having the windows drawn and the seats reclined. "Men have become suffering creatures as a consequence of their moralities: what they have purchased with them is, all in all, a feeling that at bottom they are too good and too significant for the earth and are paying it only a passing visit." (D, 182)

Disenabling any sort of response to suffering, as in a compassion that seeks only to eradicate it, disables the sort of ethical work on ourselves Nietzsche applauds: "In every noble morality [pity] is considered a weakness...pity negates life, it makes life worthy of negation." 20 To affirm this life, on the other hand, would be to affirm it as a place where we are made, become through struggle and so suffering. Nietzsche explains this point at length in suggesting that attentiveness to the ennobling aspects of suffering fosters a concomitant attentiveness to our role in shaping the project that is humanity:

In human beings, creature and creator are combined: in humans there is material, fragments, abundance, clay, dirt, nonsense, chaos; but in humans there is also creator, maker, hammer-hardness, spectator-divinity and seventh day: - do you understand this contrast? And that your pity is aimed at the "creature in humans," at what needs to be molded, broken, forged, torn, burnt, seared and purified, - at what necessarily needs to suffer and should suffer? ${ }^{21}$

Compassion figures prominently in Thus Spoke Zarathustra, a work in which Nietzsche is attempting to show humanity to itself in its decline so that it might move towards its overcoming. Nietzsche wants to say that the rise of compassion figures integrally in this decline. In Book II, Zarathustra meditates on shared suffering in "Of the Compassionate," where he contrasts compassion with a healthier form of being with others, what he simply calls "love." Distinctive for Zarathustra about love is that it is creative, it says yes to existence. "Thus speaks all great love: it overcomes even forgiveness and pity....All great love is above pity: for it wants - to create what is loved!" (Z, 114) Nietzsche returns to the problem of compassion in the final book of Zarathustra, where compassion is described as

${ }^{20}$ Nietzsche, Anti-Christ, 7.

${ }^{21}$ Nietzsche, Beyond Good and Evil, 117. 
Zarathustra's last or ultimate (letzte) sin. A quotation from Book II's "Of the Compassionate" serves as an epigraph to Book IV:

Alas, where in the world have there been greater follies than with the compassionate? And what in the world has caused more suffering than the follies of the compassionate? Woe to all lovers who cannot surmount pity! Thus spoke the Devil to me once: Even God has his Hell: it is his love for man. And I lately heard him say these words: God is dead; God has died of his pity for man. $(\mathrm{Z}, 249)$

Rather than simply to avoid compassion, Nietzsche's challenge is to envision a form of fellow feeling that surmounts suffering as a basis of our ethical relation to others. Importantly, it is lovers who are called to do this: we do not overcome compassion in the name of extinguishing all fellow feeling, we don't deny any and all connection to others. Instead, we transform the way we relate to others, we learn to share not suffering but joy.

Book IV narrates just this transformation. Zarathustra there overcomes compassion as he discovers a more affirmative relation to others. At the outset, Zarathustra is outside of his cave when he encounters a prophet who announces, "Pity!.... O Zarathustra, I come to seduce you to your ultimate sin." $(Z, 255)$ The prophet is Schopenhauer: Zarathustra calls him "the prophet of the great weariness"; he tells Zarathustra, "it is all one, nothing is worthwhile, the world is without meaning..." (Z, 254) Since compassion is for Schopenhauer the chief or ultimate virtue, that it is here called the ultimate sin points to the stage at which we find Zarathustra in his wanderings. He is halfway through the project of overcoming compassion, having revalued it as a sin rather than a virtue, but not yet having overcome it, for he still feels its pull. Zarathustra hears a cry of distress, the cry is described as that of the higher man, and it sends Zarathustra out to find the suffering figure and alleviate his pain, to express compassion for his higher man.

Zarathustra seeks out the distressed crier, trying to attend to suffering, but in the end is never able to locate and placate the sufferer he seeks. Instead, Zarathustra is able to satisfy his compassion for the higher man only once he overcomes it through joy, avoiding the seduction of Schopenhauer by revaluing suffering as integral to the best sort of life. Zarathustra comes to understand that the higher men are not those for whom he waits, overhumans. "You do not understand me" $(\mathrm{Z}, 330)$ he says; "they are not my rightful companions!" (Z, 333) The ugliest man seems to affirm life, to want it once more, saying: "Was that - life? For Zarathustra's sake, very well! 
Once more!'” $(\mathrm{Z}, 326)$ His affirmation, though, is not yet complete because it remains ascetic. He says yes to this world only by seeing it in the light of an ideal he takes to transcend it, here the teachings of Zarathustra. Not life as its own justification, not life beautiful in its terror, but life justified through something that transcends it, life falsely affirmed through non-life.

And precisely here, where Zarathustra distances himself from the higher men he had sought, Nietzsche turns to joy. Zarathustra says that he waits for "stronger, more victorious, more joyful men, such as are square-built in body and soul: laughing lions must come!" (Z, 294) He congratulates the higher men for their ability to despise themselves, as a first step towards overcoming themselves, but insists that despising says only "no" and that they still need to learn how to say "yes." $(Z, 307)$ Yes is laughter, yes is joy. "You have not learned to play and mock..." $(\mathrm{Z}, 303)$ Zarathustra relates all of this to the higher men, happily, in song, through a series of aphorisms on joy:

For joy, though woe be deep: Joy is deeper than heart's agony. (Z, 331)

Did you ever say yes to one joy? 0 my friends, then you said Yes to all woe as well. All things are chained and entwined together, all things are in love. (Z, 331-32)

What does joy not want! it is thirstier, warmer, hungrier, more fearful, more secret than all woe, it wants itself; it bites into itself...it wants love, it wants hatred, it is superabundant, it gives, it throws away, begs for someone to take it, thanks him who takes, it would like to be hated; so rich is joy that it thirsts for woe, for Hell, for hatred, for shame, for the lame, for the world - for it knows, oh it knows this world! (Z, 332)

Not a suffering that is redeemed in another world, not suffering as balancing the scales, but a joy in love with all things, a joy that revalues with its embrace, that says "pain is also joy." $(Z, 331)$

We see joy here intertwined with an affirmation of eternal return, Nietzsche's ultimate formula for affirming existence, and precisely here we can isolate the difference between Schopenhauer and Nietzsche. Schopenhauer considered eternal return as a formula of affirmation but argued that, in the face of the ubiquity of suffering, any person would say no to it. (WW1, 323-26) Nietzsche, of course, says yes. Nietzsche says yes to a certain affective orientation to the world that Schopenhauer thinks impossible; Nietzsche wants us to 
want the world. In the above aphorisms from $Z$, the English "joy" is used to translate Nietzsche's Lust. "Joy" is the best English translation of the German, but Lust connotes too desire and (erotic) striving. Joy for Nietzsche is intertwined with desire, affirmation is a kind of lust, and Nietzsche turns to the type of desire given form in our relationships to help him to articulate his ethical vision for human beings.

\section{Friendship, Joy, and Affirmation}

Others occupy a contested place in Nietzsche's thought. While Nietzsche is often understood as the arch-individualist, I think that David Mikics is on the right track when he writes that, "in Nietzsche...identity remains (at times promisingly, at times maddeningly) subject to the other person who, we hope, might unlock the mystery of the self for us." 22 Nietzsche is interested in the economies that exist among people, economies of feeling, ideas, and valuations that can help to select and shape the material that is in us such that we become new. He writes, "how I rejoice in any mood and secret transformation within myself which means that the ideas of another have prevailed over my own!" (D, 189) He goes so far as to locate what is best about those we love as their bringing with them a different estimation of life: "what is love but understanding and rejoicing at the fact that another lives, feels and acts in a way different from and opposite to ours?" (HH, 229-30) Part of our propensity for reading Nietzsche as an individualist is the undeniable place of exemplary individuals in his thinking. For Nietzsche, though, it is lamentable that such heroes can exist only as solitary exceptions to the increasing mediocrity of the human being of slave morality. He looks often to the Greeks as fostering the communal conditions for individual superlative achievement. Nietzsche credits our relationships with the potential to reawaken in us incitement or striving for existence he recognized among the Greeks but saw as silenced by slave morality. In our relationships with others we are afforded the opportunity to reconnect with those processes of creation through what Nietzsche will call self-overcoming. So it is that we find Nietzsche often praising those who are able to take on, to feel or want a host of perspectives, to enjoy and affirm a sense of self as multiple, open to the many and varied currents of existence and the overcom-

22 David Mikics, The Romance of Individualism in Emerson and Nietzsche (Athens: Ohio University Press, 2003), 2. 
ing of the self that they can work. A note from 1885 reads: "deep disinclination to settle down comfortably once and for all in any single overall view of the world; charm of the opposite way of thinking; refusal to be robbed of the attraction of the enigmatic." 23 Nietzsche, again in this vein: "the type we are representing is one of our possibilities - we could form many persons - we do have the material for that in us." 24

We saw above that when our relationships are prefigured by shared suffering, we risk becoming incapable of affirming life. Where "you lose strength when you pity" 25 in a note Nietzsche writes, "Mitfreude increases the force of the world." 26 Where compassion preaches nothingness, withdrawal, the ennui of a particular form of nihilism, Nietzsche sees joy, its production and affirmation, as worldmaking. Attending only to suffering is attending only to the ways the world breaks us down; in attending to joy, Nietzsche will suggest, we attend to the way that we can be put back together, and Nietzsche wants to say that we can come to joy by sharing it.

For Schopenhauer, we can act morally only in response to another's suffering; joy, on the other hand, invites only envy (BM, 146). While Mitleid is strictly speaking concern for the other's wellbeing, Schopenhauer insists that given the envious nature of human beings, it is not possible for us to be with others in their joys, only insofar as they suffer. We are, Schopenhauer maintains, mistrustful of the joys of others. He quotes Rousseau as he writes, "it is not peculiar to the human heart to put itself in the position of those who are more fortunate than we, but only of those who are more pitiable" (BM, 146), and adds: "even the sight of success and enjoyment purely as such can easily excite envy, to which everyone is prone." (BM, 146) Schopenhauer's dubiousness about sharing joy is not, for Nietzsche, incidental. Nietzsche sees the suspicion of joy as symptomatic of slave morality's more general suspicion of all life-affirming values. He writes, "the reverse side of Christian compassion for the suffering of one's neighbour is a profound suspicion of all the joy of one's neighbour, of his joy in all that he wants to do and can." (D, 48) ${ }^{27}$

23 Friedrich Nietzsche, Writings from the Late Notebooks, (tr.) K. Sturge, (ed.) R. Bittner (Cambridge: Cambridge University Press, 2003), 91.

${ }^{24}$ Friedrich Nietzsche, Kritische Gesamtausgabe, vol. 7, no. 2, (ed.) G. Colli and M. Montinari (Berlin: Walter de Gruyter, 1974), 103. See also in vol. 7, no. 2, 13.

25 Nietzsche, Anti-Christ, 6.

${ }^{26}$ Friedrich Nietzsche, Kritische Gesamtausgabe, vol. 5, no. 1, (ed.) G. Colli, M. Montinari, W. Müller-Lauter and K. Pestalozzi (Berlin: Walter de Gruyter, 1971), 707.

27 See also Nietzsche, Anti-Christ, 17-18. 
Schopenhauer's pessimism begins, must begin, with the 'no' of suffering, of will denied.

For Schopenhauer, it is not just that it is not in the nature of human beings to share in each other's joy, but also that suffering can claim an ontological priority over joy. For him, joy is merely the temporary alleviation of suffering, and so is nothing in itself. (BM, 146) Joy as positive, as a desire that is its own end, is Nietzsche's answer to Schopenhauer here. Nietzsche turns to joy as he turns to a yes-saying spirit that is joyful, giving, and affirmative. Joan Stambaugh writes that for Nietzsche, "joy is an active participant in what it encounters." 28 Joy says yes to itself in wanting itself in everything, wanting everything joyful. Where joy affirms everything, suffering wants nothing, wills nothingness: "Woe says: Fade! Go! But all joy wants eternity, wants deep, deep, deep eternity!" (Z, 335)

Nietzsche champions relationships of shared joy because they involve the type of affirmation of the world that he would have us cultivate. "We are experiments," Nietzsche writes. "Let us also want to be them!" (D, 191) It is this wanting, this striving, that Nietzsche articulates through joy, and glimpses as a possibility in the best relationships. Love for Nietzsche joins lovers in their becoming. ${ }^{29}$ Nietzsche sees as best about us our capacity to be undone, unsettled, to allow ourselves to come apart in a frenzy that allies itself to the world. He writes of love:

...there is no more confused or impenetrable spectacle than that which arises when both parties are passionately in love with one another and both consequently abandon themselves and want to be the same as one another: in the end neither knows what he is supposed to be imitating, what dissimulating, what pretending to be. The beautiful madness of this spectacle is too good for this world and too subtle for human eyes. (D, 211)

Lovers surrender to each other in the way Nietzsche would have us surrender to the world; friends share a thirst similar to but higher than lovers. They allow themselves to be unsettled, but want to give themselves not just to the other but to the world, so that they can become whatever the world will make of them. (GS, 89) This capacity of friends to open each other up to their overcoming through joy is

\footnotetext{
28 Joan Stambaugh, "All Joy Wants Eternity," Nietzsche-Studien, vol. 33 (2004): 335-41, here 338.

29 See Leslie Paul Thiele, "Love and Judgement: Nietzsche's Dilemma," NietzscheStudien, vol. 20 (1991): 88-108, here 90.
} 
for Nietzsche the essence of friendship. Nietzsche writes: "here and there on earth we may encounter a kind of continuation of love in which this possessive craving of two people for each other gives way to a new desire and lust for possession - a shared higher thirst for an ideal above them. But who knows such love? Who has experienced it? Its right name is friendship." (GS, 89) In Z, Nietzsche is more explicit about this higher ideal, suggesting the friend should be "an arrow and a longing" for the overhuman. ${ }^{30}(\mathrm{Z}, 83)$

Friends point towards our self-overcoming by showing us to ourselves as tenuous, unfinished beings dependent on the world to make us what we are. In "Of the Friend" from $Z$, the friend is referred to as a third term that supplements the complacent conversation between the self and itself. "I and me are always too earnestly in conversation with one another: how could it be endured, if there were not a friend? For the hermit the friend is always the third person: the third person is the cork that prevents the conversation of the other two from sinking to the depths." $(\mathrm{Z}, 82)$ A contemporaneous note reads: "I and Me are always two different persons." 31 Nietzsche says through Zarathustra that "your love of the neighbour is your bad love of yourselves" (Z, 86). Nietzsche's German is better than the English here, for nächstenliebe, charity or love of the neighbour, is more literally love of the nearest, an ambiguity Nietzsche plays with when he next counsels instead Fernsten-Liebe, "love of the farthest." (Z, 87) Rather than the neighbour, who comforts by confirming our current beliefs, Nietzsche wants human beings to strive for something other, to see themselves as becoming other, and insists our friendships figure in this work. Nietzsche writes of a phantom, ghost or spectre [Gespenst] that stands in for the person we might become: "This phantom that runs along behind you, my brother, is fairer than you; why do you no give it your flesh and bones? But you are afraid and you run to your neighbour." $(\mathrm{Z}, 87)$ Importantly, Nietzsche wants to push us out of this fearful complacency through the figure of the friend: "I wish rather that you could not endure to be with any kind of neighbour or with your neigh-

${ }^{30}$ Robert C. Miner has argued that the goal of friendship is truth in "Nietzsche on Friendship," Journal of Nietzsche Studies, vol. 40 (2010): 47-69. Miner quotes Nietzsche in The Gay Science where he calls friendship "a shared higher thirst for an ideal above them" (GS 14) and suggests that this ideal is truth. Yet aphorism 279 of the same work, friends are described as having separate, divisive goals. In "Of the Friend" from $Z$, there are several claims that friendships flourish where knowledge is absent.

31 Friedrich Nietzsche, Kritische Studienausgabe, vol. 10, (ed.) G. Colli, M. Montinari (Berlin: Walter de Gruyter, 1980), 96. 
bour's neighbour; then you would have to create your friend and his overflowing heart out of yourselves." (Z, 87)

This work particular to friendship necessitates a degree of contest and conflict, shown perhaps most clearly by Nietzsche's metaphor of the friend as enemy. We read that, "if you want a friend, you must also be willing to wage war for him: and to wage war, you must be capable of being an enemy." ( $\mathrm{Z}, 82)$ The intimacy particular to friendship will include struggle, friendship will hold within itself enmity. It is a particular form of intimacy that allows itself sometimes to turn vitriolic; to welcome enmity is to allow the friend, and through the friend the world, to have a say in what we are, who we are becoming, it is to seek the strength of submitting oneself to forces one helps to constitute without claiming control over. Nietzsche stresses that the enmity of friendship is instrumental; rather than buttressing a sophomoric masculinity, friendships will involve enmity as the marker of a commitment to the other's becoming. It is because we aim to foster the friend's overcoming that we must sometimes be an enemy to their present.

The call to sometimes be an enemy to our friends delivers to us a ponderous responsibility. Insofar as we are a friend not to the friend as she is but as she is becoming, Nietzsche will suggest we must sometimes sever ourselves from a friend if we realize they would be better off without us:

Friends in need. - Sometimes we notice that one of our friends belongs more to another than he does to us, and that his delicacy is troubled by and his selfishness inadequate to this decision: we then have to make things easier for him and estrange him from us... [0] ur love for him has to drive us, through an injustice which we take upon ourself, to create for him a good conscience in renouncing us. (D, 200-201)

We have to traffic with the other's spectral self even or especially when they are not yet able to do so. Nietzsche writes of this ideal, spectral self:

Many live in awe of and abasement before their ideal and would like to deny it: they are afraid of their higher self because when it speaks it speaks imperiously. It possesses, moreover, a spectral freedom to come or to stay away as it wishes; on this account it is often called a gift of the gods, whereas in reality it is everything else that is a gift of the gods (of chance): this however is man himself. $(\mathrm{HH}, 197)$ 
Here Nietzsche suggests that what is most ours as human beings is the possibility of our growing into ourselves through overcoming, what he here calls a spectral freedom. Our friends are friends to this becoming, this possibility or spectre, rather than to ourselves as we are. And since this spectral freedom to become is the human being herself, that we can be more attached to the friend's becoming than they suggests that, as Michael Ure writes, friends "exist outside of themselves or in the relationship between [them]." 32

Due to enmity at the heart of the best friendships, such relationships will be inherently fragile. Nietzsche works hard to celebrate the precariousness of human relationships because their precariousness is the precariousness of life. In celebrating how life can drive us apart, in not regretting that our paths, however intertwined, might lead us finally to depart from one another, Nietzsche wants to affirm friendships in their affirmation of the joy of a life lived. ${ }^{33}$ "[E]ven life's mistakes have their own meaning and value, the occasional side roads and wrong turns, the delays..." 34 Although Nietzsche comes to distance himself from Richard Wagner, he does not wish to deny or regret their friendship, for it played its part in his becoming himself: "Perhaps nobody was more dangerously attached to - grown together with - Wagnerizing; nobody tried harder to resist it; nobody was happier to be rid of it. A long story! — You want a word for it? - If I were a moralist, who knows what I might call it? Perhaps self-overcoming." 35 It is only the best of friendships whose demise we can celebrate, for we affirm their end as part of a process, an opening, and we celebrate the end or parting as productive. "In parting. - It is not how one soul approaches another but in how it distances itself from it that I recognize their affinity and relatedness." (HH, 275)

The spectral attachment of friendship bars any easy reciprocation between friends. Nietzsche will write that "we find it more pain-

\footnotetext{
32 Michael Ure, Nietzsche's Therapy: Self-Cultivation in the Middle Works (Lanham: Lexington Books, 2008), 231.

${ }^{33}$ Paul van Tongeren suggests that Nietzsche, in turning to the language of deceit and disguise means to suggest that true friendship is impossible, in "Politics, Friendship and Solitude in Nietzsche: (Confronting Derrida's reading of Nietzsche in 'Politics of Friendship')," South African Journal of Philosophy, vol. 19, no. 3 (2000): 209-22. This is unsatisfying because Nietzsche's often-used method of persuasive redefinition preserves a sense of many concepts even as he shows that they are not what they pretend to be.

34 Nietzsche, Ecce Homo, 96.

35 Friedrich Nietzsche, The Case of Wagner, (tr,) W. Kaufmann (New York: Vintage Books, 1967), 155 .
} 
ful...when one of our friends makes himself guilty of something shameful than when we do so ourselves....our love for him is stronger than his own love for himself." (HH, 37) And Zarathustra says, "should your friend do you a wrong, then say: 'I forgive you what you did to me; but that you did it to yourself - how could I forgive that?'” $(Z, 114)$ Nietzsche writes of the friend that "we believe...in the purity of his character more than he does...the unegoistic in us - this word is never to be taken in a strict sense but only as a simplified form of expression - is affected more strongly by his guilt than is the unegoistic in him." (HH, 37) Returning to the thought that Nietzsche wants to preserve a relationality that does not fall into the erasure of compassion, we can see him here pointing at the same time towards and away from the unegoistic. When the friend occupies her place in our thinking, her concerns take over our own as in Schopenhauer's compassion, but only in a "simplified form of expression," for what is crucial for Nietzsche is that they remain her concerns, her spectral freedom. ${ }^{36}$

Importantly, the lack of reciprocity is, for Nietzsche, productive. Friends give flesh to the ghost of the other's ideal self, make real what the other is becoming by reflecting it back, not perfectly, but enticingly, as an object of desire. Zarathustra asks: "have you ever watched your friend asleep - to discover what he looked like? Yet your friend's face is something else beside. It is your own face, in a rough and imperfect mirror. Have you ever watched your friend asleep? Were you not startled to see what he looked like? 0 my friend, man is something that must be overcome." $(\mathrm{Z}, 83)$ There is reflection, like in a mirror, but a broken mirror that sends us out to find ourselves in between each other. Nietzsche returns often to the thought that friends serve as other worlds. We behold the friend's face in sleep; the sleeping friend is not one world or another put the beautiful possibility of passage between them. We read that, "for every soul, every other soul is an afterworld [Hinterwelt]." (Z, 234) Joan Stambaugh makes a point of translating Hinterwelt more literally as "backworld," accepting some awkwardness in exchange for the benefit of connoting something like a backstage or background that serves to make our lives intelligible. Nietzsche writes of "the friend in whom the world stands complete, a vessel of the good - the

\footnotetext{
36 Bernard Reginster discusses this aspect of Nietzsche's criticism of Schopenhauer on compassion in "Compassion and Selflessness," in Nietzsche, Naturalism, and Normativity, (ed.) C. Janaway, S. Robertson (Oxford: Oxford University Press, 2012), 160-82.
} 
creative friend, who always has a complete world to bestow." (Z, 88) The second self of the friend is not one thing reflecting back, but an opening onto the numberless possibility of growing out of ourselves into something new, a ghost to whom we might give our flesh and bones. Not what I am for myself, not what I am for my friend, but the change that takes place between two, a doubling that appears out in a world affirmed as joy by being shared.

\section{Friendship and Strong Surrendering}

Friendship is able to play this role because it involves the type of joyful giving of oneself over to forces that one does not control that Nietzsche respected so much. That Nietzsche celebrates a certain way of giving oneself helps to resolve a seeming tension in his views. For while he calls often for a noble type of person who is proud and resolute, he also calls for self-overcoming, becoming other, seeing ourselves as experiments, and putting ourselves at risk. The apparent contradiction between these two imperatives dissolves in agonistic relationships, in which enmity and struggle are given a place to appear, where strength displays itself by giving ground. Nietzsche's account of strength comes in the form of what I call a strong surrendering, an ethical posture that animates Nietzsche's account of friendship.

With Nietzsche we so often find divergent imperatives placed in opposition, so that the task of Nietzsche's reader is to conceptualize a figure or form of human feeling able to contain and celebrate rather than suffer from contradiction. In this vein, Nietzsche describes as a prerequisite for revaluing values the combining of "contradictory abilities that could not be allowed to disturb or destroy one another." 37 In terms of the human subject, Nietzsche points to the dual, potentially contradictory imperatives of affirming wholeheartedly one's particular perspective or valuation of the world while also remaining able to give it up. Nietzsche calls on us to, Wolfgang Müller-Lauter writes, "achieve this twofold attitude, belief and simultaneous readiness to give up belief.... It would, then, be not only changing assent, surrendering again and again to the varying perspectives and constantly re-solidifying, but simultaneously assenting to the changing itself." ${ }^{38}$ Nietzsche's figure of the overhuman represents

\footnotetext{
37 Nietzsche, Ecce Homo, 97.

38 Wolfgang Müller-Lauter, Nietzsche: His Philosophy of Contradictions and the Contradictions of his Philosophy, (tr.) D. Parent (Urbana: University of Illinois
} 
what it would mean to embody both imperatives. Her strength is displayed in the first place by an increase in power evinced by imposing her ideal upon the world, making others understand the world through her eyes. While some stop here and see Nietzsche as heralding a megalomaniacal creator, Nietzsche also stresses a second imperative for the overhuman, that she remain open to the multiplicity of perspectives, not just acquiesce to but affirm the fact that hers is one of a world of perspectives. This is because when the overhuman allies herself with power, with the will to power, it is not her power, her control, but the power or pulse of a world she affirms as becoming, as joy. We embrace the strength to see ourselves as beholden to a world that makes us rather than the weakness of standing apart.

It is no surprise, then, that we often find Nietzsche linking strength with giving way or surrender and often within earshot of friendship. In a passage on self-overcoming, we read that yes, the weak yields to the stronger, but "...the greatest, too, surrenders and for the sake of power stakes - life. The devotion of the greatest is to encounter risk and danger and play dice for death." $(Z, 138)$ Nietzsche writes elsewhere that "he who really possesses himself...henceforth regards it as his own privilege to punish himself, to pardon himself, to take pity on himself: he does not need to concede this to anyone else, but he can freely relinquish it to another, to a friend for example." (D, 186-87). He suggests that "to relinquish one's rights - gives pleasure when it indicates great wealth. Magnanimity belongs here." (D, 158) He also writes of an imperative to "give away, to give back, to communicate, to grow poorer!... To be in possession of a dominion and at the same time concealed and renouncing.... That would be a life!" (D, 189) Strength for Nietzsche manifests itself not in a withdrawal from but with exposure to forces that would undo that strength. Finally, and succinctly, in a cryptic passage Nietzsche points to "the two species of happiness (the feeling of power and the feeling of surrender)." (D, 36)

Nietzsche wants to say that one of the ways we give ourselves over, feel joy in surrender, is the say we give to others in who we are. We are not beings who stand apart, "fully-developed facts" (D, 225), doers behind deeds; we are, instead, beings through whom the world can move and in so moving make whole the multiplicities that we are. Our friends help us to do this, help us to become who we are, beings who can feel joy in the face of becoming. And so Nietzsche will

Press, 1999), 68. See also Robert Pippin, Nietzsche, Psychology, and First Philosophy (Chicago: University of Chicago Press, 2010), 113. 
call friendship Mitfreude, shared joy. Such an account points to a more general ethical picture that sees us linked to others not through suffering, guilt, and obligation but through joy, through lines of becoming that show us tangled up with others and everything in a beautiful spectacle that, when affirmed, shows the world in all its innocence. We owe our existence to a world that makes us, but this is not a debt or an obligation but a beautiful opportunity, like the surrender we take on in love, like meeting someone we like.

danieliharris@outlook.com 